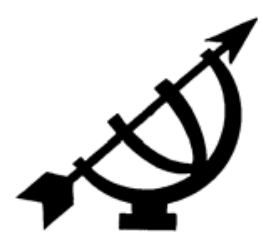

\title{
The gospel of reconciliation and healing in the Alps: Johanna Spyri's Heidi reconsidered
}

\author{
Frederick Hale \\ Department of English \\ University of Stellenbosch \\ STELLENBOSCH \\ E-mail: fh243@cam.ac.uk
}

\begin{abstract}
The gospel of reconciliation and healing in the Alps: Johanna Spyri's Heidi reconsidered

Johanna Spyri's renowned novel of 1880, "Heidi", is best known internationally through countless translations, abridgements, cultural adaptations, and film adaptations since the late nineteenth century. In many of these permutations of the original German text, the fundamental Christian message has been either significantly reduced or eliminated entirely. As an active member of the Reformed Church in Zürich whose early life was influenced by Pietism, Spyri imbued many of her works for children and adults with explicitly religious dimensions. In "Heidi", these are manifested in the protagonist's spiritual maturation, her grandfather's reconciliation with God and his neighbours through the parable of the prodigal son, and the restoration of health and mobility aided by Christian charity and a wholesome lifestyle. It is argued that the religious currents in "Heidi" and Spyri's other works have been fundamentally misunderstood by earlier critics such as Wolgast and Doderer.
\end{abstract}

\section{Opsomming}

Die evangelie van versoening en genesing in die Alpe: Johanna Spyri se Heidi weer in oënskou geneem

Johanna Spyri se beroemde roman, "Heidi" (1880), is wêreldwyd goed bekend deur talle vertalings, verkortings, kulturele aanpassings en films sedert die laat negentiende eeu. In die meeste van hierdie verwerkings van die oorspronklike Duitse teks is die basiese Christelike boodskap aanmerklik verkort of 
heeltemal verwyder. Spyri was 'n aktiewe lidmaat van die Gerformeerde Kerk in Zürich en in haar jong dae is sy sterk deur die Piëtisme beïnvloed. Daar is 'n duidelike godsdienstige dimensie in baie van haar boeke vir kinders en volwassenes. In "Heidi" word dit gesien in die geestelike groei van Heidi, haar Oupa se versoening met God en sy bure, geïnspireer deur die lees van die gelykenis van die verlore seun, en die genesing van 'n verlamde Duitse meisie deur Christelike liefde en 'n gesonde lewenswyse. Die artikel redeneer dat die godsdienstige temas van Heidi deur vroeëre kritici, soos Wolgast en Doderer, tot 'n groot mate misverstaan is.

\section{A legacy of misinterpretation}

Johanna Spyri's internationally renowned Heidi (1880) became a victim of its own success. Initially published as Heidi's Lehr- und Wanderjahre and Heidi kann gebrauchen, was es gelehrt hat in 1880 and 1881, respectively, it was translated into numerous other European languages before 1900, and early in the twentieth century it was rendered into many others, even appearing in a Japanese edition in the 1920s. Eventually dozens of abridgements and culturally adapted versions of the story were produced, as were several motion pictures. Some of these translations and renditions were faithful to Spyri's original message, but in the hands of countless profiteers Heidi underwent permutations of Alpine proportions. ${ }^{1}$

Notwithstanding their immense international popularity, Heidi and the other stories by Spyri have been the subject of relatively little serious scholarly inquiry. That religious motifs permeate her writing has been a truism in critical commentary on these celebrated works. Precisely what the spiritual themes in them are, however, and how they function within Spyri's ideational world remain much less well understood, and patently false assertions about the matter have long burdened the secondary literature about this author. A fresh look at this crucial dimension of the two-part Heidi novel is thus in order. In the present article it is my purpose to take steps towards clarifying the religious elements in Spyri's best-known work by identifying crucial weaknesses in the pertinent criticism and

1 No fully satisfactory translation of the original German text of the two volumes of Heidi has ever been published. In the present article the quotations are taken from that by Eileen Hall, originally published in 1956. All page references are to Spyri (1995). For serious research in the German Urtext, see Spyri (1880). 
highlighting both the kind of Christian themes and the limits of the Christianity which she proclaimed therein.

Certain roots of the misconceptions lie in the nineteenth century. As early as 1896 Heinrich Wolgast (1860-1920), a teacher in Hamburg who more than nearly anyone else pioneered the study of children's literature in Germany and was possibly the first scholar to publish deprecating views of Spyri's authorship, took her to task for burdening her writing with moralistic and religious motifs. She stood head and shoulders above most other contemporary female authors of fiction for children, he allowed, and demonstrated talent in virtually everything she published. But in the final analysis her spiritual preoccupation had led to at least a partial lowering of aesthetic standards: "At times the literary sap flows strongly and freshly, succeeding in transforming the religious and moral themes into lively forms; at other times, however, it is weak and faltering, and the realm of religion and morality remain dead weight ..." (Wolgast, 1905:188). Less defensibly, Wolgast generalised categorically that everyone in Spyri's gallery of characters could be pigeonholed in two categories, namely "paragons of virtue and villains", and that within this Manichean construction the religiously inclined persons were "without exception exemplary and virtuous". Furthermore, this critic, who nowhere evinced an adequate degree of comprehension of theological matters for making evaluations of them, insisted that in Spyri's fiction "all the events have their causes and effects in the world of nature, but the religious mentality of the author allows her characters to see and honour the hand of God in everything" (Wolgast, 1905:188-189). Wolgast adduced almost no evidence to substantiate these categorical indictments of Spyri's allegedly crassly simplistic representation of Christian spiritual life in her expansive fictional corpus.

Nearly three-quarters of a century later another specialist in the realm of German children's literature, Klaus Doderer, echoed similar sentiments about the Manichean gallery of characters in Heidi. He acknowledged that Spyri had created a relatively broad spectrum of personae, but quite in accord with Wolgast, he believed that "on closer examination it is possible to recognise that the other characters in the novel are divided into two clusters". In the one camp were those who "are distinguished by the virtue of Christian piety and by leading lives of charity and helpfulness", such as the two grandmothers, Clara Sesemann's wealthy father, and his friend, Dr. Classen. Doderer thought that Spyri had created merely two characters in the opposite camp, namely Miss Rottenmeier and 
Heidi's grandfather, popularly known as "Alm-Oehi" but called "Uncle Alp" in the English translation here used. Intimately related to this alleged characterisation, Doderer also briefly noted that there was another crassly Manichean dichotomy between wholesome highland and destructive urban life in Heidi (Doderer, 1969:124, 129-130).

With regard to the Christian dimensions of Heidi, the interpretive frameworks which Wolgast and Doderer proposed are untenable and misleading. Both overlook the diversity of the characters Spyri created and fail to come to grips with the fact that some of those people, as individuals and as members of groups, cannot be neatly pigeonholed into the binary categories which their interpretations require. Owing in large measure to this myopia, Wolgast and Doderer neglected much of the essential Christian message which Spyri had conveyed in a way less crass than they suggested. Because Heidi hinges thematically on her presentation of a variety of both rural and urban characters, and her development of a few of them, a dispassionate consideration of these Swiss and Germans is essential to an understanding of Spyri's presentation of her pivotal spiritual message.

\section{Mountaineers and urban dwellers}

The ostensibly wholesome Alpine villagers in general, and particularly those who are identified as the collective active membership of the church in Dörfli, staunchly resist the typing that Wolgast and Doderer imposed on them, and a handful undergo attitudinal transformations which run counter to a Manichean understanding of the story. The opening chapter hardly presents a flattering picture of mountain folk. Heidi's maternal aunt, Dete, shows concern for the girl but is impatient and a bit brusque with her. Moreover, her language is at times severe, as she in exasperation calls Heidi "naughty" and "stupid" (Spyri, 1995:16). When they reach Alm-Oehi's hut on the mountain, Dete pressures the initially reluctant old man through rhetorical manipulation into accepting responsibility for Heidi: "I shouldn't think you'd want anything more on your conscience," she reminds him (Spyri, 1995: 18). At no time is Dete described as either a religious or an irreligious person.

When the young man (Alm-Oehi) who later becomes the grandfather of Heidi returned to his native village of Domleschg in the canton of Graubünden after his dissolute years in Italy and elsewhere with a young son at his side, its residents shunned him completely. After turning his back on them, he settled in Dörfli, only to discover that 
no-one trusted him; rumours also circulated that he had deserted an Italian army and possibly killed a man in a brawl. The uncharitable attitude of two village populations thus alienated this native son, driving him into seclusion and long-term bitterness. The death of his son, Tobias (the father of Heidi), in a construction accident and subsequent death of his bereaved daughter-in-law "set tongues wagging" as these events were popularly attributed to God's wrath for the father's reprobate early years (Spyri, 1995:12-13).

Many years later, however, the members of the local congregation in Dörfli, to which he had moved, do a remarkable volte-face when Alm-Oehi, having been influenced by Heidi's reading of the parable of the prodigal son, finally appears in their church. Upon noticing him and the young girl in their midst, they quickly take a more positive attitude towards him, and before the end of the morning "they all changed their minds" and "began to feel quite friendly towards him". Later in the day the spirit of forgiveness is so fulsome that "they begged him to visit them in their homes before long" (Spyri, 1995:147-148). These are profound - if not literally plausible nuances in Spyri's characterisation of Swiss mountain folk which run counter to the binarism which is postulated in the interpretations of Wolgast and Doderer.

In Frankfurt, meanwhile, the cast of characters do not fit the simplified categories any better than the mountaineers of Graubünden. Some are gruff and jaded, others mild and beneficent, but the line of demarcation separating the two camps is not the line between religiosity and irreligiosity. What the villainous Miss Rottenmeier's spiritual condition may be, is simply not stated. Almost the same can be said of Clara's business-like father, who takes a charitable interest in Heidi and clearly cares about her wellbeing. Only near the end of the narrative, when thanking Alm-Oehi for his part in bringing about the restoration of his daughter's health and mobility, does this German gentleman make even a passing reference to God (Spyri, 1995:233). The private tutor who instructs both Clara and Heidi is tolerant and pleads the latter's case, arguing to Mr. Sesemann that the Swiss girl must be treated with great patience because of her lack of prior educational experience. This position seems to be professionally motivated, however, and not a function of his religious convictions, which in any case are nowhere stated. Dr. Classen is particularly benevolent, but again this may be attributable to his professional background. In general, the urban characters in Heidi, regardless of their personalities and virtues, are portrayed as secular people. One cannot, therefore, make 
correlations between their social standing and their attitudes towards Christianity.

The clear exception, of course, is Clara's paternal grandmother, the elderly Mrs. Sesemann, who takes Heidi under her wing, nurturing her Christian spirituality and consoling her with regard to prayer. Showing noteworthy spiritual maturity and perhaps talking over the girl's head, this urbane lady makes a profound impact on Heidi, who believes that her prayers have been to no avail, by assuring her of God's love and desire to help us in his time. She counsels the young Swiss to ask for divine forgiveness and greater faith (Spyri, 1995:109-110), words which are heeded and relayed in an equally effective way after Heidi returns to her grandfather.

Nor, for that matter, do the clergymen - both of whom are villagers alight neatly in the pigeonholes of the Wolgast-Doderer categorisation. The anonymous first of the two fares poorly under Spyri's pen. Referred to only briefly in retrospect, he had blundered badly when counselling Alm-Oehi after the latter's son had lost his life. Apparently having accepted the popular local attitude that the mishap had been divine punishment for the elderly man's misconduct many years earlier, this pastor is said to have "told him he ought to do penance to clear his conscience". That condemnation implicit in such a judgment alienated Alm-Oehi, who in the wake of the clergyman's visit had become "more angry than ever, and morose too" so that "he wouldn't speak to anyone after the Pastor's visit, and his neighbours began to keep out of his way" (Spyri, 1995:13). The pastor's successor, however, is a model of Christian warmth and an instrument of reconciliation. When grandfather and granddaughter call at the manse after finally attending a service, he receives them "so warmly that at first the lonely old man could hardly speak" (Spyri, 1995:147). "I shall always welcome you as a dear friend and neighbour," the pastor assures Alm-Oehi, "and I look forward to our spending many pleasant winter evenings together" (Spyri, 1995:148). Nothing about this cleric's behaviour is described negatively.

\section{Spyri's underlying Christian message}

What kind of religious message, then, did Spyri proclaim through her story? Some commentators have called it "pietistic" without defining 
that term or adducing substantial evidence to link Heidi to pietism.2 It is apparently true that Spyri had close ties to pietistic trends in the Swiss Reformed Church, but her spiritual constitution in the late 1870 s when she wrote Heidi is a matter of conjecture. At the root of the problem lies the virtual impossibility of knowing enough about Spyri to reconstruct her religious perspective at any given point in her life. As Rosmarie Zeller, one of the editors of her sparse extant correspondence has noted, Spyri actively covered her tracks by requesting people to return letters she had written so that they could be destroyed and did not believe that biographies conveyed the truth about their subjects (Zeller, 1977:9). It is nevertheless generally accepted that Spyri, whose mother's father was a Swiss Reformed pastor, grew up in a pietistic home in the village of Hirzel, near Zürich, and for confirmation instruction was sent to a conservative pietist, Antistes Füssli, in that city. Furthermore, it is known that for decades as an adult there she maintained close ties with the pietistically inclined Betsy Meyer-Ulrich, the mother of the renowned poet and novelist Conrad Ferdinand Meyer, and was a frequent guest in her home (Fröhlich \& Winckler, 1986:59). Spyri's early published writing, such as her novella of 1871, Ein Blatt auf Vronys Grab, and stories she contributed to Pastor Cornelius Rudolf Vietor's Kirchenblatt in Bremen, tended to be intensely religious. After the early 1870s, however, she did not publish anything until 1878. If Regine Schindler is correct, by then Spyri had distanced herself somewhat from the pietism of her family of origin (Schindler, 1999:180-181).

In any case, the overall religious outlook underlying Heidi, though clearly Christian, does not clearly reflect any particular genre of Christianity represented in Switzerland during the nineteenth century, apart from, in the most general terms, Protestantism as seen in the references to the two pastors and the citations of Protestant hymns. Whether either Calvin or Zwingli would have recognised his theological and ecclesiastical emphases, is questionable. There are, to be sure, references to the absolute sovereignty of God, but little else that was distinctively Calvinistic or Zwinglian. Double predestination, to cite one obvious hallmark of Calvinism, is certainly not an explicit theme in Heidi, nor is limited atonement. There is no reference to such distinctively Calvinistic matters as a quasi-theocratic model of relations between church and

2 The classic though outdated historical study of Swiss Pietism is Wilhelm Hadorn (1901). 
state, Calvinistic views of the sacraments, or the belief that all human works apart from Christian faith are sins. Some of these matters, to be sure, are simply not relevant to the plot of Heidi, while others are central to it.

But is the religious outlook of Heidi pietism, as has been alleged? Certainly dimensions of it overlap with emphases typical of pietism. One finds a great deal of personal piety on the part of two elderly ladies, namely the grandmothers of Peter and Clara, manifested especially in prayer, devotion to the Bible, and an emphasis on hymnody and devotional materials. At a child's level Heidi follows in their wake, but this expression of faith does not really characterise anyone else, with the partial exception of her grandfather. Such typically pietistic elements as the ordo salutis, or path towards sanctification, is not part of this book for young readers.

The religious factors which are mentioned or at least clearly implicit in Heidi can be listed succinctly: God, church, pastors, Bible, daily prayer, the efficacy of prayer, hymns, repentance, confession of sin, reconciliation with God and with other people, baptism, the parable of the prodigal son, and heaven. On the other hand, many elements of Christianity are conspicuously absent or at least not explicitly mentioned, e.g. Jesus Christ, Holy Spirit, creeds, liturgy, gifts of the spirit, original sin, absolution, cross, resurrection, atonement, communion, eschatology, God's judgement, and hell. Occupying a middle ground - implied but not stated - are such topics as the fruits of the Spirit and God's creation of the world. It is almost as if Spyri consciously based her story on a reductive, common-denominator sort of Christianity which would be palatable to a broad range of Christian readers.

Fundamental to Spyri's presentation of the faith is her concept of God, which one can discern in Heidi but which is not, of course, presented in a systematic, doctrinal way apart from Mrs. Sesemann's teaching about prayer and providence. God is implied to be primarily transcendent and theistic. One can pray to God and, as Mrs. Sesemann emphasises in her detailed conversation with the disillusioned Heidi in Frankfurt, God decides whether to answer prayers according to whether the requests therein are good for us. Accordingly, there is much implied emphasis on divine providence. Much of God's intervention in the world is indirect, made through the village pastor, the two grandmothers, Heidi, and other people. Communication with God is thus depicted primarily as making requests and giving thanks, but also in the hymns which are quoted in part. Though transcendent, God intervenes in the world, 
bestowing faith, healing and reconciliation. However, in places of the text God is immanent as well as transcendent and is especially approachable on the mountains. That is in itself a strong motif in Heidi. Of course, there are numerous precedents in Christianity and Judaism, and one can find much Biblical symbolism in the narrative.

In any case, the conventional Christian, theistic presentation of divinity in Heidi is not pantheistic, despite the healing power of environment. Yet God is clearly more approachable and, apparently, helps people more effectively in the village and on the mountains than in Frankfurt. However, there is no strict geographic line of demarcation. After all, in Frankfurt one finds Clara's pious grandmother, and it is there that Heidi learns to pray and trust God, largely through that elderly Christian.

Spyri may have perceived a spiritual gap separating the generations in Switzerland. Explicitly expressed Christian faith is conspicuously absent from most of the younger characters - at least those who are mentioned by name - apart from Heidi. By contrast in general it is older characters in Heidi who are more pious. Praying with grandmothers is specifically underscored. The pastor in Dörfli is also an elderly man.

\subsection{Heidi: the path to spiritual maturity}

Heidi is above all else a Christian Bildungsroman, the story of its eponymous protagonist's spiritual formation and how, after coming to faith in a compassionate God (and, it should be added, Jesus Christ is nowhere mentioned in the narrative), she serves as an instrument of God's message of reconciliation and healing. At the beginning of the narrative, when Heidi enters the guardianship of her grandfather, she is only five years old and, though charming and friendly to man and beast alike, she evinces no Christian influence on her early life. Only later, in Chapter ten, is it revealed that at an even younger age she had prayed with one of her grandmothers (Spyri, 1995:105). There is not even a hint that she was baptised in the Swiss Reformed Church or any other denomination, though of course that was conventional practice. Alm-Oehi, at that stage, is disaffected from formal religious life and makes no spiritual impact on his granddaughter. The figure who gives her initial guidance in that respect is her playmate Peter's pious, blind grandmother, who apparently plants a seed which subsequently germinates in Frankfurt. It is this elderly woman's Christian spirit, which comes to expression in her love for Heidi and her life of prayer and hymnody, which quietly influences the young girl during the two years she 
spends in her grandfather's care before going to Frankfurt. Heidi and her grandfather visit her often, he to assist her with the maintenance of her modest house. "God keep the child safe and Uncle Alp in a good humour,' was the old woman's constant prayer," the narrator emphasises (Spyri, 1995:50).

No less influential in Heidi's spiritual formation is Clara's grandmother, Mrs. Sesemann, with whom Heidi comes into contact repeatedly in Frankfurt. In their first encounter, this woman establishes rapport by being friendly to the Swiss girl and imploring her to address her as "Grandmamma" (Spyri, 1995:99-100). She also gives Heidi books which are initially unidentified but readers subsequently learn include a volume of Bible stories. Upon learning of the girl's unrelenting sadness, Mrs. Sesemann expresses concern in a candid conversation which Spyri uses to underscore the importance of prayer. She assures the obviously troubled Heidi that "if we're in trouble and can't tell any ordinary person, why, there is always God whom we can tell, and if we ask Him to help us, He always will." This assurance marks a turning point in Heidi's life, when she takes her supplications to God, especially with regard to her intense longing to return to the Alps and her grandfather (Spyri, 1995:104-105).

Subsequently, Mrs. Sesemann voices more a sophisticated understanding of prayer, arguably in words which might soar above the heads of many children of Heidi's age. The girl, still in Frankfurt, gives up communicating with God when her prayers to return to Switzerland go unanswered. Mrs. Sesemann addresses the problem squarely: "God is a loving Father to us all and knows what is good for us. If we ask for something it isn't right for us to have, He won't give it to us, but in His own good time, if we go on praying and trust in Him, He'll find something better." She also broaches the matter of divine forgiveness, assuring Heidi that God will forgive her for not continuing to pray and indeed will increase her faith and trust in providence. The girl heeds these words (Spyri, 1995:109-110), not only in Frankfurt but also after returning to Graubünden, where the Christian faith which has been nurtured in her during her time in the German city aids in the spiritual healing of her grandfather and the restoration of Clara's mobility, as will be discussed below.

\subsection{Alm-Oehi: a fictional transfiguration of the prodigal son}

Spyri employs the second most important character in the plot, Heidi's grandfather, as a postfigurative type of the prodigal son to illustrate the necessity of repentance, forgiveness, and re- 
conciliation. The transformation the aged man undergoes under the influence of the gospel is profound though not total. Notwithstanding the negative image he long has in the village, Alm-Oehi invariably treats Heidi with kindness. From the day of her arrival she elicits a beneficent strain in him, and at times he does favours for Peter's mother and blind grandmother. Yet he harbours strong resentment and hostility towards the villagers in general. He is alienated from the church until Heidi returns from Frankfurt, illustrated Bible story book in hand, and, armed with the hitherto cited message which Mrs. Sesemann has imparted to her, is prepared to serve as a vehicle of God's proclamation of forgiveness and reconciliation.

Spyri artfully lays out the background for this in the way she narrates in Chapter one the man's morally encumbered early life. Dete, who is the sister of Alm-Oehi's late daughter-in-law, relates to one of the villagers that he had been raised on "one of the best farms in Domleschg" and was the elder of two sons. He had left home, however, travelled about, "got into bad company, and drank and gambled away the whole property". Instead of repenting at that time and being warmly welcomed home, he had remained overseas for more than an additional decade and, after the deaths of his parents and brother, returned to Domleschg with a young son only to find "all doors closed against him. Nobody wanted to have anything to do with him" (Spyri, 1995:12). This is far from a fully fledged allegory of the parable of the prodigal son, of course, and the outcome is significantly different, but readers with a measure of familiarity with Luke 15 will none the less immediately recognise it as being inspired by that very well-known text. In the third chapter the old man's bitterness comes to expression when his granddaughter asks him about the croaking of a hawk. "He's jeering at all the people who live in the villages down below and make trouble for one another," replies Alm-Oehi. The narrator explains that "the old man spoke these words so fiercely that it really reminded Heidi of the croaking of the great bird" (Spyri, 1995:37-38). The kindly village pastor attempts to help him overcome his estrangement. Calling on the elderly man in an unsuccessful effort to convince him to place his granddaughter in the local school, he tells Alm-Oehi that he is "at odds with God and man" and pleads with him to move from the mountain into the village "and be reconciled to God and to your neighbours". The old man is adamant, however, believing that "the people there despise me and I them, so it's better for us to keep apart" (Spyri, 1995:53-54). 
Spyri returns to the theme of forgiveness and reconciliation in Chapter fourteen, using Heidi's assurance to her grandfather that if they pray diligently, God would not forget them, an assertion which he initially rejects on the grounds of his experience and ongoing alienation from the villages that no-one ever forgets. "If God forsakes a man, that's final," Alm-Oehi declares, clearly alluding to his own situation. "There's no going back then." Evincing spiritual maturity beyond her years, Heidi opens her well-worn Bible story book to the retelling of the prodigal son parable in which the young man says, upon returning home, "Father, I have done wrong against Heaven and against you and am no longer worthy to be your son", a slight paraphrase of the pertinent text. That night the old man folds his hands to pray and, mirabile dictu, utters the correct words of Luke 15:18-19, suggesting that he had learned them properly in his youth (Spyri, 1995:142-145). This incident, one of the most detailed in Heidi, marks a turning point in his life, a return to God, Christian fellowship, and happiness.

\subsection{Peter: resentment, anger, forgiveness}

Spyri employs one of the principal secondary characters, the goatherd Peter, for conveying fundamental Christian lessons about the nature of sin and the centrality of forgiveness. In this instance, Heidi is not a direct conduit of the gospel but a passive factor in the plot. When the ill Clara visits Heidi, these two spend most of their time together, leaving virtually no time for Peter, who is clearly enamoured of Heidi. In his bitter resentment, he clandestinely pushes Clara's wheelchair over a cliff. In what may have been inspired by Genesis 50:20, in which Joseph assures his brothers that their evil-intended behaviour towards him actually served a divine purpose, Spyri draws an indirect cause and effect relationship between the jealous boy's misdeed and Clara's regaining of her mobility. As the wheelchair is no longer available, Heidi, with the reluctant aid of Peter, encourages the partially lame German girl to try to walk. After a few halting attempts, Clara succeeds. Shortly thereafter, the spiritually mature Mrs. Sesemann visits them, and Peter confesses his part in the destruction of the wheelchair. Mrs. Sesemann immediately uses this occasion to teach a crucial lesson and declare forgiveness. "Instead of injuring her, you've actually done her good. Without her chair, Clara has had to make a special effort to walk, and you see she has succeeded," she states. "That's the way God brings good out of evil." In the same homiletical conversation, when addressing Peter's initial efforts to conceal his culpability, Mrs. Sesemann voices basic instruction about the divine 
conscience: "But you make a great mistake if you think you can do wrong and no one will know about it. God sees and hears everything, and when He notices someone trying to hide what they have done, He stirs up the little watchman we all have inside us - a little watchman who sleeps until we do something wrong" (Spyri, 1995:230-231). This is Spyri at her most didactic.

\subsection{Clara: exemplifying the healing power of God's creation}

It is at least arguable that only in her construction of Clara's healing does Spyri wander from what many theologically informed Swiss Reformed Christians would accept as conventional Christian verities. Apart from its fundamental implausibility, the incident and remarks by both Heidi and Clara approach a pantheistic concept of divinity. There are, admittedly, clear Biblical precedents for perceiving the hand of God in nature, and this comes to expression in inter alia the notion of El Shaddai, God of the mountains, where divinity is experienced more intimately and with greater majesty than in, for example, urban environments. The hilly and mountainous landscape of the Biblical lands provided a wealth of imagery for writers of the Old Testament as well as the New, and there are approximately 500 references thereto. Although many of these are merely geographically designative rather than poetic, the expressions of religious meaning and metaphors stemming from them are also common. Among these is the notion of the holy mountain, the special abode of God where people encounter the divine more directly than at lower altitudes. In much of the Old Testament, this is Mount Sinai, where Moses receives the Ten Commandments. Elsewhere, Abraham has one of his special experiences on a mountain in Genesis 22, and God appears to Moses on Mount Horeb in Exodus 3. After the settlement of Israel in the Promised Land, Zion replaces Sinai as the principal dwelling place of God on earth. It takes on eschatological and other theological significance as a place to which the righteous will stream, as in Isaiah 2, rather than a remote, unpopulated one from which people are generally excluded.

Spyri certainly makes much of a general Alpine version of this attitude towards mountains. "Isn't it heavenly up here with Grandfather?" asks Heidi (Spyri, 1995:205). The old man attributes Clara's recovery to "God's good sun and His mountain air" (Spyri, 1995:224). Clara, viewing the star-strewn firmament with Heidi, exclaims that "it feels as if we were riding in a high sort of carriage right into heaven," and her youthful hostess offers an explanation for 
the twinkling of the stars which links them to divine providence: "Because they are up in heaven and know that God looks after us all on earth so that we oughtn't really ever to be afraid, because everything is bound to come right in the end" (Spyri, 1995:203).

The restoration of Clara's general health and the recovery of her ability to walk are attributed to several causes. Three natural ones are the mountain air, which is cited repeatedly as an invigorating element, abundant sunshine, which is implicitly contrasted with the darker environment in Frankfurt, where Clara has spent little time outdoors, and the food she consumes in the Alps, especially goat's milk. Rural victuals are described as much more palatable than those of that city (Spyri, 1995:208). But Heidi's dynamic intervention is also crucial. Initially she suggests that she could carry the older girl to a different section of the mountain pasture in order to see its flora, a proposal which Clara dismisses as unrealistic. At that point Heidi, in a rare moment of anger, presses Peter into service and, supporting Clara between them, they assist her in taking her first steps. All of this occurs after Clara has received unidentified treatment for approximately six weeks at Ragaz (Spyri, 1995:192). There is no mention of prayer for her healing, although after it is a fait accompli some of the others express their gratitude to God as well as to Heidi and her grandfather for their instrumental parts.

\section{Conclusion}

Heidi is not a theological roman à thèse. Not that the adolescent age group for which it was primarily intended would have categorically ruled out a treatment of certain doctrinal issues; indeed, some are either implicitly or explicitly present in the text. But in none of her works did Spyri attempt to tackle the thorny theological issues which were continuing to plague Protestantism in her country in the1870s. The religious elements in Heidi do not directly (and perhaps not even obliquely) address the theological fissures that ran through the Reformed churches of Switzerland at that time. In conditions which varied greatly from one canton to another, Swiss Protestantism was sharply divided into mutually hostile camps. There was nothing new about this during Spyri's years of literary creativity. It had been a recurrent theme in the ecclesiastical history of Switzerland for several decades and gained a great deal of public attention in, for example, the successful conservative resistance to the appointment of the radical German theologian David Friedrich Strauss, to a professorship in Zürich in 1839 and the unsuccessful efforts to halt the appointment of Eduard Zeller to a similar position in Bern eight 
years later. But the war of words was becoming more heated and structured when Spyri took up her authorial pen, partly because the belligerent parties organised formal associations for the advancement of their positions. The "Freisinnigen", or modernisers, founded their "Kirchlicher Reformverein" in 1866 to promote theological liberalism, reform the confessions and liturgy of the church, and offer alternatives to pietistic modes of spirituality. The conservative reaction came to fruition five years later when the "Evangelischen", also called the "Positiven", constituted their "Schweizerischer Evangelisch-kirchlicher Verein", which inter alia upheld traditional doctrinal formulations and declared that the Apostles' Creed should remain in use as part of the sacrament of baptism. As the eminent Swiss church historian Rudolf Pfister pointed out, both parties were well represented in the cantons of Zürich, Bern, Graubünden, Aargau, Basel city, and Geneva (Pfister, 1984:261-267). In some cities, the acrimony, especially that arising from disputes over the calling of pastors and the election of ecclesiastical officials, was so great that certain large parishes found it necessary to have two clergymen, one whose ministry was directed primarily at the liberal members and the other at the conservatives in the divided flock. As Pfister observed, on the local level tensions over these matters disaffected large numbers of Swiss Reformed Christians who either withdrew and joined nonconformist churches which had spread to Switzerland or gave up on organised religious life generally. This trend, which was also noticeable in many other European countries, occurred simultaneously with the turning away from ecclesiastical life by many Swiss intellectuals and much of the nation's working class (Pfister, 1984:268).

To be sure, although these disputes and divisions adversely affected popular church life, not least in Zürich, they were not universal in Switzerland and did not necessarily made an impact on village religiosity and personal piety as manifested in e.g. Peter's grandmother. That said, one could arguably suggest that in Spyri's fictional world the emphasis on personal ethics (rather than social ethics) and on reconciliation between people and with God are closer to the conservative side, while in a default sense practical Christian living devoid of theological refinements harmonises with liberal theology. However, in the end Heidi does not suggest that Spyri was consciously attempting to support either side.

The contextualised study of Spyri's Heidi as a fundamentally religious book underscores the necessity of investigating the 
Christian dimensions in her other works, some of which were published by a Christian agency in Bremen. They have received considerably less scholarly attention than Heidi but are nevertheless a vital part of the legacy of Swiss and German literature, not only that written for children. And that, in turn, points to the desirability of taking a fresh look at how Christianity has been presented to young readers by other writers in Switzerland and other countries where the Reformed tradition has been strong. Decades of research into such literature has illuminated many hitherto dark corners but left countless others tenebrous.

\section{List of references}

DODERER, K., Red. 1969. Klassische Kinder-und Jugendbücher: kritische Betrachtungen. Weinheim: Beltz.

FRÖHLICH, R. \& WINCKLER, J. 1986. Johanna Spyri: Momente einer Biographie - ein Dialog. Zürich: Arche.

HADORN, W. 1901. Geschichte des Pietismus in den Schweizerischen Reformierten Kirchen. Konstanz: Hirsch.

PFISTER, R. 1984. Kirchengeschichte der Schweiz. Band 3: von 1720 bis 1950. Zürich: Theologischer Verlag.

SCHINDLER, R. 1999. Form und Function religiöser Elemente in Johanna Spyris Werken. (In Rutschmann, Verena, Red. Nebenan: der Anteil der Schweiz an der deutschsprachigen Kinder- und Jugendliteratur. Zürich: Chronos.

SPYRI, J. 1880. Heidi's Lehr- und Wanderjahre: eine Geschichte für Kinder und auch für Solche, welche die Kinder lieb haben. Gotha: Perthes.

SPYRI, J. 1995. Heidi. London: Penguin Books.

WOLGAST, H. 1905. Das Elend unserer Jugendliteratur. Leipzig: Teubner.

ZELLER, H. \& R., Reds. 1977. Johanna Spyri Conrad Ferdinand Meyer Briefwechsel 1877-1897. Kilchberg: Verlag Mirio Romano.

\section{Key concepts:}

healing

Heidi

reconciliation

Spyri

Swiss literature

Kernbegrippe:

genesing

Heidi

Spyri

Switserse letterkunde

versoening 